\title{
IMPLEMENTASI KEBIJAKAN PENEMPATAN POS-POS BADAN PENANGGULANGAN BENCANA DAN PEMADAM KEBAKARAN KOTA PALEMBANG
}

\author{
Citra Iasha \\ Dosen Sekolah Tinggi Ilmu Administrasi (STIA) Satya Negara Palembang \\ Email: citraiasha1977@gmail.com
}

\begin{abstract}
The background of the problem of high fire frequency from year to year in the Palembang City area shows that the fire prevention efforts carried out by the Palembang City Fire Department organization. In South Sumatra there are many strategic places for various sector centers to support the provincial capital. For example, the center of the economy, business, entertainment, education, and the government of Jakarta as the center of the country and the density of settlements so that there is often a fire hazard. The purpose of this research is to find out how the implementation of the policy of placing the posts of disaster management agencies and firefighters in Palembang city. This research is a qualitative study using data collection methods in the form of interviews with predetermined sources. The results of this study are based on observations and interviews by the author that the implementation of policies carried out by the disaster management agency and the Palembang city fire department has gone well, this is based on the results of interviews using indicators put forward by almost all informants saying it is quite good and already good. This means that the implementation of policies for aligning disaster management and fire fighting agency posts has been good.
\end{abstract}

Keywords: Policy Implementation, Pos-pos, BPBPK

\begin{abstract}
ABSTRAK
Latar belakang masalah frekuensi kebakaran yang tinggi dari tahun ke tahun di wilayah Kota Palembang menunjukkan bahwa upaya pencegahan kebakaran yang dilakukan oleh organisasi Dinas Pemadam Kebakaran Kota Palembang. Di sumatera selatan banyak tempat-tempat yang strategis untuk berbagai macam sentra bidang sebagai penunjang ibu kota Propinsi. Seperti sentra ekonomi, bisnis, hiburan, pendidikan, dan pemerintahan Jakarta sebagai pusat negara dan padatnya pemukiman sehingga sering terjadi bahaya kebakaran. Tujuan dari penelitian ini adalah untuk mengetahui bagaimana implementasi kebijakan penempatan pos-pos badan penanggulangan bencana dan pemadam kebakaran kota palembang. Penelitian ini merupakan penelitian kualitatif dengan menggunakan metode pengumpulan data berupa wawancara dengan narasumber yang sudah ditentukan. Hasil penelitian ini berdasarkan observasi dan wawancara yang penulis lakukan bahwa implementasi kebijakan yang dilakukan oleh badan penanggulangan bencana dan pemadam kebakaran kota palembang telah berjalan dengan baik, hal ini berdasarkan dari hasil wawancara dengan menggunakan indikator yang dikemukakan hampir semua informan mengatakan cukup baik dan sudah baik. Artinya implementasi kebiajkan penepatan pos-pos badan penanggulangan bencana dan pemadam kebakaran sudah baik.
\end{abstract}

Kata Kunci: Implementasi Kebijakan, Pos-pos, BPBPK

\section{A. PENDAHULUAN}

Kota Palembang adalah ibu kota provinsi Sumatera Selatan. Palembang merupakan kota terbesar kedua di Sumatera setelah Medan. Kota Palembang memiliki luas wilayah 400,61 $\mathrm{Km} 2$ yang dihuni 1,7 juta orang dengan kepadatan penduduk 4.800 per $\mathrm{km}^{2}$. Kota ini akan diwacanakan akan menjadi ibukota
Indonesia. Diprediksikan pada tahun 2030 mendatang Kota ini akan dihuni 2,5 Juta orang. Di wilayah ini banyak tempat-tempat yang strategis untuk berbagai macam sentra bidang sebagai penunjang ibu kota Propinsi. Seperti sentra ekonomi, bisnis, hiburan, pendidikan, dan pemerintahan. Banyaknya tempat-tempat strategis tersebut ditambah lagi dengan 
tingginya tingkat kepadatan penduduk, mengakibatkan kemungkinan terjadinya hambatan atau hal-hal yang tidak diinginkan. Seperti tindakan kejahatan, kemacetan, banjir dan lain sebagainya. Tak ketinggalan pula bencana kebakaran yang dapat terjadi setiap saat.

Kebakaran di Kota Palembang menurut Suku Dinas (SUDIN) Pemadam Kebakaran mencatat, pada tahun 2013, tingkat kebakaran di Kota Palembang menjadi nomor satu paling tinggi di Propinsi Sumatera Selatan. Berdasarkan data Badan Penanggulangan Bencana dan Pemadam Kebakaran (BPBPK), tercatat sampai tri wulan pertama tahun 2012 jumlah kebakaran sampai akhir April yakni sebanyak lebih kurang ada 25 kejadian. Sedangkan untuk tri wulan pertama tahun 2013 ini, kebakaran hanya 15 kasus kebakaran yang terjadi. Penyebab utama kebakaran adalah akibat listrik, sama dengan tahun lalu. Dari 15 kejadian kebakaran tahun 2013 ini, sekitar 70 persen disebabkan oleh hubungan pendek arus listrik. "Namun dari 15 kejadian yang ada, terjadi di rumah toko (Ruko) seperti di Pasar Cinde, Pasar 16 dan yang lainnya,.

Tingginya tingkat kebakaran didukung banyaknya pemukiman padat penduduk. Kecamatan Kertapati dan Tangga Buntung merupakan dua kecamatan yang paling rawan terjadi kasus kebakaran. Rumah penduduk di kedua kecamatan tersebut, mayoritas terdiri dari bahan yang mudah terbakar, seperti kayu dan tripleks.

Usaha penanggulangan kebakaran sangatlah berhubungan dengan berbagai macam aspek pendukung seperti letak pos pemadam kebakaran, Rumah Sakit, hydrant, kemacetan lalu lintas dan jarak lokasi. Dengan mengetahuai posisi aspek pendukung diatas maka proses penanggulangan bahaya kebakaran akan lebih cepat dilakukan dan diminimalisir jumlah korban serta kerugian yang ditimbulkan oleh bencana tersebut.

Dikarenakan tingginya tingkat kebakaran yang terjadi di Kota Palembang dan pendataan pada Dinas Pemadam Kebakaran Kota Palembang perlu untuk melakukan suatu kebijakan dalam memberikan pelayanan kepada masyarakat dengan cepat, untuk itu perlu diadakannya tempat-tempat pos pelayanan pemadam kebakran yang mudah dihubungi dan jarak tempuh yang dekat dengan lokasi terjadinya kebakaran.

Frekuensi kebakaran yang tinggi dari tahun ke tahun di wilayah Kota Palembang menunjukkan bahwa upaya pencegahan kebakaran yang dilakukan oleh organisasi Dinas Pemadam Kebakaran Kota Palembang belum optimal. Angka kerugian akibat kebakaran dari setiap kasus kebakaran yang terjadi menunjukkan bahwa upaya pemadam kebakaran yang dilakukan oleh Dinas Pemadam Kebakaran Kota Palembang belum efektif. Akibatnya masyarakat cenderung bersikap sinis terhadap petugas pemadam kebakaran yang menurut mereka selalu datang terlambat di lokasi kebakaran sehingga upaya pemadam kebakaran menjadi tidak efektif dan mengakibatkan tingkat kerugian yang lebih tinggi.

Permasalahan terlihat jelas bila kebakaran terjadi berbarengan pada tempat berbeda, jumlah unit mobil pemadam dirasakan kurang. Dengan jumlah pos yang hanya 5 (lima) membuat jarak tempuh ke lokasi kejadian menjadi tinggi, sehingga pada saat sampai dilokasi kemungkinan besar telah terjadi flashover, kondisi dimana api telah melahap sebagian besar bangunan. Jika dilihat dari kemampuan adalah sangat tidak mungkin Dinas Penanggulangan Bahaya Kebakaran Kota Palembang dapat melayani kebutuhan dengan efektif, dengan jumlah penduduk sebesar satu setengah juta jiwa.

Hydran-hydran yang ada di Kota Palembang belum dapat dipergunakan secara efektif bila terjadi kebakaran. Luas Kota Palembang sebesar 400,61 $\mathrm{KM}^{2}$ tidak dapat dilayani secara optimal dengan jumlah dan kondisi hidran yang terbatas. Upaya yang dilakukan Dinas Penanggulangan Bahaya Kebakaran Kota Palembang dalam usaha memenuhi kebutuhan air adalah dengan mengambil dari anak-anak sungai dan kolam retensi, kedua sumber ini sangat tergantung dengan kondisi alam. Bila kejadian kebakaran di pusat kota air diambil dari Sungai Musi dan Kolam Air Mancur. Belum terpenuhinya kebutuhan air penanggulangan kebakaran berjalan lambat dan beresiko terjadinya penjalaran yang luas. 
Kendala yang dihadapi dalam menanggulangi bahaya kebakaran sebagai berikut :

a. Belum adanya sumber air yang memadai

b. Jalan dan lorong yang sempit

c. Kemacetan lalu lintas pada jam sibuk

d. Adanya gapura dan portal

e. Belum adanya kesadaran untuk melengkapi bangunan dengan alat proteksi bahaya kebakaran.

Pelayanan tidak efektif dikarenakan cakupan jangkauan pelayanan yang begitu luas. Luasan yang mampu dicakup secara efektif oleh satu wilayah Manajemen Kebakaran dalam Manajemen penanggulangan kebakaran Kota tidak melebihi radius 7,5 km dan daerah yang sudah terbangun harus mendapat perlindungan oleh pelayanan penanggulangan kebakaran yang pos terdekatnya berada pada jarak 2,5 km.

Untuk itu perlu dirumuskan kebijakan untuk dapat mengatasi permasalahan ini. Sehubungan dengan itu maka penelitian ini dilakukan dengan tujuan untuk (a) mengidentifikasi faktor-faktor yang menghambat dalam memutuskan kebijakan penempatan pos-pos pemadam kebakaran; (b) melakukan evaluasi terhadap kebijakankebijakan yang telah di laksanakan. Adapun pos-pos yang telah tersedia untuk saati ini di Kota Palembang berlokasi di 5 titik yaitu: Pos Pemadam Merdeka, Pos Pemadam Ulu, Pos Pemadam Gandus, Pos Pemadam AAL dan Pos Pemadam Sako. Sarana mobil pemadam kebakaran pada pos-pos pembantu hanya 2 unit mobil dengan jumlah keseluruhan mobil yang ada pada Badan Penanggulan Bencana dan Pemadam Kebakaran Kota Palembang di jalan merdeka 18 unit mobil. Untuk memberikan bantuan apabila terjadi kebakaran di pos pembantu masih kekurangan mobil pemadam kebakaran apabila terjadi kebakaran besar dengan jumlah mobil 2 unit, karena tidak semua mobil apabila dibutuhkan seketika dapat beroperasi dengan baik.

Berdasarkan uraian diatas, dirasakan perlu untuk melakukan penelitian tentang Implementasi Kebijakan secara lebih intensif untuk mengetahui aspek-aspek mana yang akan menjadi prioritas untuk dapat diperbaiki dan aspek-aspek mana yang harus dipertahankan. Untuk itu penelitian ini ditujukan untuk meningkatkan pelayanan publik Berdasarkan uraian diatas, penulis berkeinginan untuk menyuguhkan penelitian dan penulisan tesis dengan judul : "Implementasi Kebijakan Penempatan PosPos Badan Penanggulangan Bencana dan Pemadam Kebakaran Kota Palembang".

\section{B. KAJIAN PUSTAKA}

Menurut Thomas R. Dye dalam Howlett dan Ramesh (2005:2), kebijakan publik adalah adalah "segala yang dikerjakan pemerintah, mengapa mereka melakukan, dan perbedaan yang dihasilkannya (what government did, why they do it, and what differences it makes)". Dalam pemahaman bahwa "keputusan" termasuk juga ketika pemerintah memutuskan untuk "tidak memutuskan" atau memutuskan untuk "tidak mengurus" suatu isu, maka pemahaman ini juga merujuk pada definisi Thomas R. Dye dalam Tilaar dan Nugroho (2008:185) yang menyatakan bahwa kebijakan publik merupakan "segala sesuatu yang dikerjakan dan tidak dikerjakan oleh pemerintah".

Kebijakan publik memiliki konsep-konsep sebagai berikut:

a. Kebijakan publik berisi tujuan, nilai-nilai, dan praktik/pelaksanaannya.

b. Kebijakan publik tersebut dibuat oleh badan pemerintah, bukan organisasi swasta.

c. Kebijakan publik tersebut menyangkut pilihan yang dilakukan atau tidak dilakukan oleh pemerintah.

Dari poin-poin di atas maka kita bisa menarik benang merah dari definisi kebijakan publik dalam Lampiran 1 Peraturan Menteri Pendayagunaan Aparatur Negara Nomor PER/04/M.PAN/4/2007 tentang Pedoman Umum Formulasi, Implementasi, Evaluasi Kinerja, dan Revisi Kebijakan Publik di Lingkungan Lembaga Pemerintah Pusat dan Daerah. Dalam Peraturan Menteri ini, kebijakan publik adalah "keputusan yang dibuat oleh pemerintah atau lembaga pemerintahan untuk mengatasi permasalahan tertentu, untuk melakukan kegiatan tertentu 
atau untuk mencapai tujuan tertentu yang berkenaan dengan kepentingan dan manfaat orang banyak". Dalam Peraturan Menteri tersebut, kebijakan publik mempunyai 2 (dua) bentuk yaitu peraturan yang terkodifikasi secara formal dan legal, dan pernyataan pejabat publik di depan publik. Menurut Subarsono (2005:3) kebijakan publik dapat berupa Undang-Undang, Peraturan Pemerintah, Peraturan Pemerintah Provinsi, Peraturan Pemerintah Kota/Kabupaten, dan Keputusan Walikota/Bupati. Berdasarkan Peraturan Menteri ini, pernyataan pejabat publik juga merupakan bagian kebijakan publik. Hal ini dapat dipahami karena pejabat publik adalah salah satu aktor kebijakan yang turut berperan dalam implementasi kebijakan itu sendiri.

Dalam kaitannya dengan topik penelitian ini, penulis akan berusaha meninjau implementasi kebijakan penempatan pos-pos pemadam kebakaran yang tercantum dalam Renstra BPBK 2010-2014. Seperti yang disimpulkan dari teori-teori proses kebijakan bahwa setelah formulasi kebijakan, maka proses yang harus dilakukan adalah proses implementasi yang menuju pada kinerja kebijakan, maka Renstra BPBK tentang penempatan pos-pos pemadam kebakaran yang telah menjadi suatu kebijakan publik juga harus melalui tahap implementasi. Dikarenakan tahap proses yang diteliti dalam tesis ini adalah tahap implementasi, maka teori-teori kebijakan yang dibahas selanjutnya adalah teori-teori implementasi kebijakan.

\section{Faktor-Faktor yang Mempengaruhi Implementasi Kebijakan}

Menurut George C. Edward III dalam Subarsono (2005:90) ada empat faktor yang berpengaruh terhadap keberhasilan atau kegagalan implementasi suatu kebijakan, yaitu faktor komunikasi, sumber daya, struktur birokrasi, dan disposisi.

\section{a. Komunikasi}

Persyaratan pertama bagi implementasi kebijakan yang efektif adalah bahwa mereka yang melaksanakan keputusan harus mengetahui apa yang harus mereka lakukan. Keputusan-keputusan kebijakan dan perintah-perintah harus diteruskan kepada personil yang tepat sebelum keputusan dan perintah-perintah tersebut dapat diikuti. Tentu saja, komunikasi harus akurat dan harus dimengeti dengan cermat. Secara umum Edwards membahas tiga hal penting dalam proses komunikasi kebijakan yakni transmisi, konsistensi dan kejelasan. Transmisi artinya sebelum pejabat dapat mengimplementasikan suatu keputusan ia harus menyadari bahwa suatu keputusan telah dibuat dan suatu perintah untuk pelaksanaannya telah dikeluarkan. Kejelasan; jika kebijakan sebagaimana yang dinginkan, maka petunjuk pelaksana tidak hanya harus diterima oleh para implementor, tetapi juga komunikasi kebijakan harus jelas. Ketidakjelasan pesan komunikasi yang disampaikan berkenaan dengan implementasi kebijakan akan mendorong terjadinya interpretasi yang salah bahkan mungkin bertentangan dengan makna pesan awal. Konsistensi, artinya bahwa jika implementasi kebijakan ingin berlangsung efektif, maka perintahperintah pelaksanaan harus konsisten dan jelas.

b. Sumber Daya

Sumber daya adalah faktor paling penting dalam implementasi kebijakan agar efektif. Sumber daya tersebut dapat berwujud sumber daya manusia, yakni kompetensi implementor, dan sumber daya financial. Tanpa adanya sumber daya, kebijakan hanya tinggal di kertas menjadi dokumen saja.

c. Disposisi (kecenderungan atau tingkah laku)

Disposisi adalah watak dan karakteristik yang dimiliki oleh implementor seperti komitmen, kejujuran dan sifat demokratis. Apabila implementor memiliki disposisi yang baik, maka dia akan dapat menjalankan kebijakan dengan baik seperti apa yang diinginkan oleh pembuat kebijakan. Ketika implemetor memiliki sifat atau perspektif yang berbeda dengan pembuat kebijakan, maka proses implementasi kebijakan juga menjadi tidak efektif.

d. Struktur Birokrasi

Struktur organisasi yang bertugas mengimplementasikan kebijakan memiliki pengaruh yang signifikan terhadap implementasi kebijakan. Salah satu dari 
aspek struktur yang paling penting dari setiap organisasi adalah adanya prosedur operasi yang standar (standar operating procedures atau SOP). SOP menjadi pedoman bagi implementor dalam bertindak. Selain itu struktur organisasi yang terlalu penjang akan cenderung melemahkan pengawasan dan menimbulkan red-tape, yakni prosedur birokrasi yang rumit dan kompleks. Dan pada akhirnya menyebabkan aktivitas organisasi tidak fleksibel.

Sedangkan menurut Van Meter dan van Horn dalam Subarsono (2005:99) menyatakan bahwa ada enam variabel yang mempengaruhi kinerja implementasi yakni:

1. Standar dan Sasaran Kebijakan

Standar dan sasaran kebijakan harus jelas dan terukur sehingga dapat direalisasikan. Apabila standard an sasaran kebijakan kabur, maka akan terjadi multiinterpretasi dan mudah menimbulkan konflik diantara para agen implementasi.

2. Sumber Daya

Implementasi kebijakan perlu dukungan sumber daya, baik sumber daya manusia maupun sumber daya non manusia.

3. Komunikasi antar Organisasi dan Penguatan Aktivitas

Dalam implementasi program perlu dukungan dan koordinasi dengan instansi lain. Untuk itu diperlukan koordinasi dan kerja sama antar instansi bagi keberhasilan suatu program.

4. Karakteristik agen pelaksana

Agar pelaksana mencakup struktur birokrasi, norma-norma, dan pola-pola hubungan yang terjadi dalam birokrasi, yang semuanya akan mempengaruhi implementasi suatu program.

5. Kondisi sosial, ekonomi dan politik

Variabel ini mencakup sumber daya ekonomi, lingkungan yang dapat mendukung keberhasilan implementasi kebijakan, sejauh mana kelompokkelompok kepentingan dapat memberikan dukungan bagi implementasi kebijakan, karakteristik para partisipan yakni mendukung atau menolak, bagaimana sifat opini publik yang ada di lingkungan dan apakah elit politik mendukung implementasi kebijakan.

6. Disposisi implementor

Disposisi implementor ini mencakup tiga hal, yakni (a) respon implementor terhadap kebijakan, yang akan dipengaruhi kemauannya untuk melaksanakan kebijakan, (b) kognisi, yakni pemahamannya terhadap kebijakan, dan (c) intensitas disposisi implementor, yakni preferensi nilai yang dimiliki oleh implementor.

Setelah membahas model-model faktor yang mempengaruhi kebijakan dari beberapa pakar, penulis mendapatkan benang merah yang menghubungkan antar satu model dengan model lain. Sepeti disebutkan sebelumnya bahwa model utama yang digunakan penelitian ini adalah model Edwards III, maka penulis mengemukakan sintesis dari model Van Meter dan Van Horn serta Grindle, berdasarkan model dasar Edwards III. Sintesis hubungan antar model-model tersebut dapat diilustrasikan sebagai berikut:

\section{Implementasi Kebijakan}

Ukuran keberhasilan maupun kegagalan dari suatu kebijakan sebagian besar ditentukan dari implementasi kebijakan, sebagaimana dikemukakan oleh Nugroho (2008: 501):

Rencana adalah $20 \%$ keberhasilan, implementasi adalah $60 \%$ sisanya, $20 \%$ sisanya adalah bagaimana kita mengendalikan implementasi. Implementasi kebijakan adalah hal yang paling berat, karena di sini masalahmasalah yang kadang tidak dijumpai dalam konsep, muncul di lapangan. Selain itu, ancaman utama, adalah konsistensi implementasi.

Jika ditinjau dari segi pelayanan, maka sebagai lembaga yang memberikan pelayanan pendidikan maka keberhasilan implementasi kebijakan di sekolah dapat pula diukur dari segi pelayanan yang dihasilkan. Pengukuran keberhasilan pelayanan dapat dilakukan dengan berbagai macam parameter. Menurut Ratminto dan Winarsih (2008: 179-182), secara garis besar pengukuran keberhasilan pelayanan dapat dilakukan berdasarkan hasil dan proses. 
1) Ukuran yang berorientasi hasil Pengukuran yag berorietasi pada hasil meliputi:
a. Efektivitas
b. Produktivitas
c. Efisiensi
d. Kepuasan
e. Keadilan

2) Ukuran yang berorientasi proses Pengukuran yang berorientasi pada proses meliputi:
a. Responsivitas
b. Responsibilitas
c. Akuntabilitas
d. Keadaptasian
e. Kelangsungan hidup
f. Keterbukaan/transparansi
g. Empati

\section{Kerangka Berpikir}

Atas dasar beragam teori-teori yang dikemukakan di landasan teori, maka kerangka berpikir dapat digambarkan sebagai berikut:

\section{Gambar I}

Kerangka Berpikir/Teori

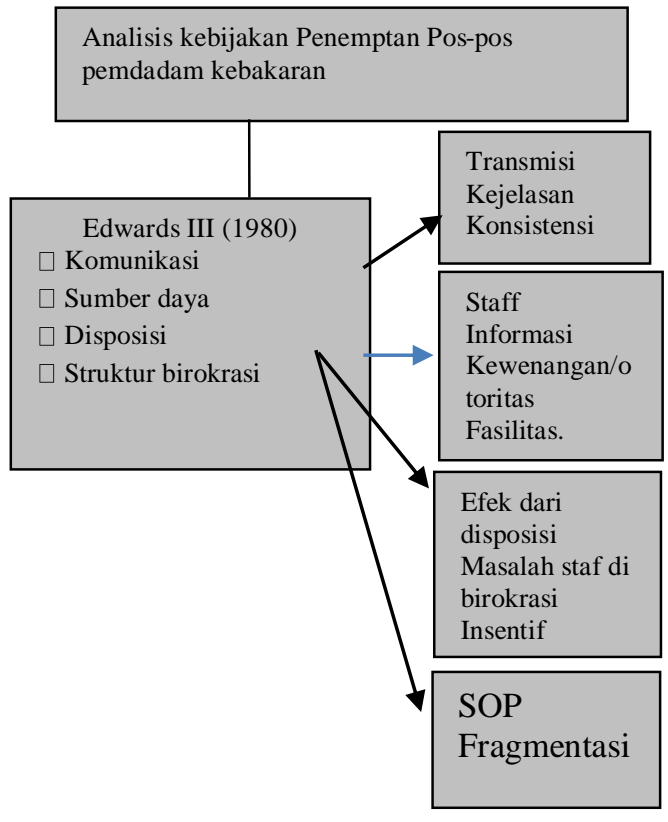

\section{METODE PENELITIAN}

Metode yang digunakan dalam penelitian ini adalah metode penelitian deskriptif dengan menggunakan pendekatan kualitatif. Sebagaimana dikatakan Nawawi (1990:64) bahwa metode deskriptif memusatkan perhatian terhadap masalah-masalah atau fenomena yang ada pada saat penelitian dilakukan atau bersifat aktual, kemudian menggambarkan fakta-fakta tentang masalah yang diselidiki sebagaimana adanya diiringi dengan interpretasi rasional yang akurat. Berdasarkan pemahaman di atas, penelitian ini menggambarkan fakta-fakta dan menjelaskan keadaan dari objek penelitian untuk mencoba menganalisa kebenarannya berdasarkan data yang diperoleh di lapangan

Variabel dalam penelitian ini adalah implementasi kebijakan pemerintah Kota Palembang. Adapun implementasi kebijakan ini dimensinya meliputi :

Tabel 1. matrik indikator

\begin{tabular}{|l|l|l|}
\hline Variabel & Dimensi & $\begin{array}{l}\text { Indikator /Definisi } \\
\text { Operasional }\end{array}$ \\
\hline $\begin{array}{l}\text { Kebijakan } \\
\text { penempatan } \\
\text { pos-pos } \\
\text { pemadam } \\
\text { kebakaran }\end{array}$ & Komunikasi & $\begin{array}{l}\text { a. Transmisi } \\
\text { b. Kejelasan } \\
\text { c. Konsisten }\end{array}$ \\
\cline { 2 - 3 } & $\begin{array}{l}\text { Sumber } \\
\text { Mana }\end{array}$ & $\begin{array}{l}\text { a. Kuantitas SDM } \\
\text { b. Kualitas SDM } \\
\text { c. Fasilitas sarana } \\
\text { prasarana }\end{array}$ \\
\cline { 2 - 3 } & Disposisi & a. Komitmen \\
\cline { 2 - 3 } & Struktur & a. SOP \\
& birokrasi & \multicolumn{2}{|l|}{} \\
\cline { 2 - 3 } & Sumber $\cdot$ Edwar II 2005:90
\end{tabular}

Informan dalam penelitian ini berjumlah 7 orang yang terdiri atas :

1. Kepala Dinas

2. Bidang kedaruratan dan logistik

3. Bidang rehabilitasi dan rekontruksi

4. Bidang sarana dan prasarana

5. Petugas/staf pemadam kebakaran

Menurut Sutopo ( 2002:21) data dalam penelitian ini dikumpulkan melalui beberapa cara yaitu:

a. Wawancara informan yaitu dimaksudkan untuk mengajukan pertanyaan secara tatap muka dengan respon yang dilakukan dengan mengajukan sejumlah pertanyaan yang diajukan secara tertulis dengan pertanyaan yang telah disiapkan. Dalam penelitian ini wawancara kepada bidang pencegahan dan kesiapsiagaan, bidang rehabilitasi dan rekontruksi, bidang kedaruratan dan logistik, bidang sarana dan prasarana dan petugas pemadam kebakaran yang ada di Lingkungan Dinas Pemadam Kebakaran Kota Palembang. 
b. Studi dokumentasi mengamati berbagai dokumen yang berkaitan dengan rumusan masalah yaitu perda-perda, arsip-arsip, laporan-laporan, buku-buku sehingga dapat menunjang pelaksanaan penelitian.

c. Observasi yaitu pengamatan langsung terhadap objek yang diteliti untuk mendapatkan gambaran yang akurat mengenai objek penelitian.

\section{HASIL DAN PEMBAHASAN}

1. Implementasi Kebijakan Penempatan Pos-Pos Badan Penanggulanagan Bencana dan Pemadam Kebakaran Kota Palembang

Pembahasan menegani Implementasi Kebijakan Penempatan Pos-Pos Badan Penanggulanagan Bencana dan Pemadam Kebakaran Kota Palembang terdiri dari hasil penelitian dan pembahasan hasil penelitian.

\section{Komunikasi}

Ada tiga hal penting yang dibahas dalam proses komunikasi, kebijakan, yakni transmisi, konsistensi, dan kejelasan (clarity). Faktor pertama, yang mendukung implementasi kebijakan adalah transmisi. Seorang pejabat yang mengimplementasikan keputusan harus menyadari bahwa suatu keputusan telah dibuat dan suatu perintah untuk pelaksanaannya telah dikeluarkan.

Faktor kedua yang mendukung implementasi kebijakan adalah kejelasan, yaitu bahwa petunjuk-pcttmjuk pelaksanaan kebijakan tidak hanya harus diterima oleh para pelaksana kebijakan, tetapi komunikasi tersebut harus jelas.

Faktor ketiga yang mendukung implementasi kebijakan adalah konsistensi, yaitu jika implementasi kebijakan ingin berlangsung efektif, maka perintah-perintah pelaksanaan harus konsisten dan jelas.

\section{a. Transmisi}

Penyaluran komunikasi yang baik akan dapat menghasilkan suatu implementasi yang baik pula. Seringkali terjadi masalah dalam penyaluran komunikasi yaitu adanya salah pengertian (miskomunikasi) yang disebabkan banyaknya tingkatan birokrasi yang harus dilalui dalam proses komunikasi, sehingga apa yang diharapkan terdirtorsi di tengah jalan.
Dalam penelitian ini penyampaian komunikasi yang dilakukan oleh warga kepada petugas pemadam kebakaran apabila terjadi kebakaran informasinya terlambat. Seperti petikan wawancara penulis kepada kepala Badan BPBPK Kota Palembang yang mengatakan:

"Memang sering terjadi dalam penyaluran penyampaian informasi terjadi keterlambatan dari konsumen atau masyarakat apabila terjadi kebakaran, dan tidak jelasnya informasi yang disampaikan sehingga petugas terlambat dalam memberikan pertolongan. Hal yang sering terjadi dalam setiap kasus terjadinya kebakaran".

Hal tersebut dibenarkan oleh kepala bidang kearuratan yang menyatakan sebagai berikut :

"Benar apa yang dikatakan oleh kepala dinas memang sering sekali terjadi penyampaian informasi yang tidak tepat atau jelas sehingga menyulitkan petugas untuk menanggapi dengan cepat apabila terjadi bencana kebakaran".

Senada dengan pernytaan di atas ditanggapi oleh petugas pemadam kebakaran sebagai berikut:

"Sebenarnya kami selalu siap siaga apabila terjadi kebakaran namun kadang informasi yang kami terima tidak jelas dan sering terlambat, sehingga pada saat kami datang kondisi gedung atau tempat yang terjadi kebakaran sudah parah karena api sudah membesar. Inilah yang terjadi setiap kali terjadi kebakaran".

Sesuai dengan kutipan wawancara di atas, dapat dijelaskan bahwa Badan Penanggulangan Bencana dan Pemadam Kebakaran Kota Palembang telah berupaya sebaik mungkin dalam penyaluran dan penyampaian informasi, hanya saja konsumen atau masyarakat yang sering kurang tepat dalam memberikan informasi.

Berdasarkan hasil wawancara tersebut serta menurut hasil observasi dapat disimpulkan bahwa pada dasarnya dalam transmisi komunikasi yang dilakukan oleh Badan Penanggulangan Bencana dan Pemadam Kebakaran sudah cukup baik hanya 
saja sering terlambat dalam menerima penyampaian informasi.

b. Konsistensi

Perintah yang diberikan dalam pelaksanaan suatu komunikasi harus konsisten dan jelas untuk ditetapkan atau dijalankan. Jika perintah yang diberikan sering berubah-ubah, maka dapat menimbulkan kebingungan bagi pelaksana di lapangan.

Berdasarkan hasil observasi dan wawancara penulis dilapangan mengenai perintah yang diberikan oleh atasan atau pimpinan dalam hal ini kepala dinas atau kepala bidang kepada pegawai dari hasil wawancara kepada petugas pemadam kebakaran saudara Ariando mengatakan:

"Kami dalam menjalankan setiap perintah dari atasan atau pimpinan selalu dikerjakan dengan cepat, karena komunikasi dalam memberikan perintah untuk melaksanakan tugas pesan yang disampaikan jelas dan dapat dipahami oleh bawahan".

Senada dengan pernyataan di atas dib oleh petunarkan oleh Kepala Dinas yang mengatakan:

"Selaku pimpinan saya berusaha sebaik mungkin tegas dalam memutuskan atau memberi perintah kepada bawahan dalam melaksanakan tugas, berusaha juga untuk tidak berubah-rubah dalam memberikan perintah yang menyebabkan bawahan bingung untuk melaksanakannya.

Hal tersebut ditanggapi oleh kepala bidang rehabilitasi dan kontruksi yang menyatakan sebagai berikut :

" Menurut pandangan saya kepala dinas sudah bekerja dengan konsisten dalam memberikan perintah kepada setiap bahawannya dalam hal pekerjaan yang akan dilaksanakan".

Senada dengan tersebut bidang sarana dan prasarana mengatakan :

" Dari yang saya ketahui selama saya menjadi staf diBadan Penanggulangan Bencana dan Pemadam Kebakaran bahwasannya kepala dinas tidak pernah memberikan perintah kepada bawahannya yang membingungkan terutama dalam hal pembagian tugas pada pos-pos pemadam kebakaran yang telah di tentukan, selalu konsisten dengan apa yang diucapkan dan disampaikan kepada bawahannya dan perintah yang dimandatkan pasti tidak berubah-rubah terkecuali apabila memang itu harus dirubah maka dia mengkoordinasikan terlebih dahulu kepada kepala-kepala bidang".

Dari beberapa pernyataan narasumber, terlihat semua narasumber berpendapat bahwa konsistensi di yang ada di pimpinan dan pegawai Badan Penanggulangan Bencana dan Pemadam Kebakaran sudah baik. Hal ini terlihat dari kepatuhan tugas dalam melaksanakan perintah atasan di karenakan perintah yang diberikan jelas dan tidak membingungkan untuk dilaksanakan karena pimpinan yang konsisten dalam memberi perintah.

c. Kejelasan

Komunikasi yang diterima oleh pelaksana kebijakan (street-level-bureaucrats) harus jelas dan tidak membingungkan atau tidak ambigu/mendua.

Kejelasan dalam penelitian ini adalah dalam melaksanakan perintah atau tugas serta kejelasan dari atasan atau pimpinan dalam hal ini kepala Badan Penanggulangan Bencana dan Pemadam Kebakaran selaku pengambil kebijakan. Berdasarkan petikan wawancara penulis kepada kepala Badan Penanggulangan Bencana dan Pemadam Kebakaran Kota Palembang yang mengatakan:

“ Selaku pimpinan saya berusaha memberikan kebijakan atau keputusan yang jelas kepada bawahan dalm hal perintah yang saya berikan dapat dipahami dan dimengerti bawahan. Perintah yang saya keluarkan tidak membingungkan dan terbagi satu-satu dalam memberikan perintah kepada bawahan, terutama dalam pembagian tugas pada pos-pos pemadam kebakaran yang telah ditentukan.”.

Hal senada wawancara kepada petugas pemadam kebakaran saudara Ariando mengatakan:

"Ya kami sebagai staf melihat bahwa pimpinan dalam hal ini kepala dinas selalu jelas dalam memberikan perintah atau membuat suatu kebijakan, seperti kami petugas yang ditempatkan di Pos- 
Pos pemadam kebakaran yang telah di sk kan diberikan kewenangan utnuk melaksanakan tugas yang telah di putuskan oleh pimpinan dalam hal memberikan pelayanan kepada masyarakat yang membutuhkan bantuan pada saat terjadi kebakaran".

Hal tersebut diatas dibenarkan oleh bidang sarana dan prasarana yang mengatakan :

"Perintah yang kami terima untuk melakukan suatu pekerjaan selalu jelas dan kamipun dalam menyampaikan kepada staf kami juga mudah tidak mengalami kesulitan dikarenakan perintah yang di berikan oleh kepala dinas jelas dan tidak terbagi-bagi”.

Dari hasil wawancara tersebut terlihat semua narasumber berpendapat bahwa kejelasan dalam pemberian perintah dari pimpinan dalam hal ini kepala dinas Badan Penanggulangan Bencana dan Pemadam Kebakaran sudah baik. Hal ini terlihat dari keputusan kebijakan dan perintah tidak membingungkan pegawai dalam melaksnakannya.

2. Sumber DayaManusia

Dalam sumber daya manusia (SDM) dalam pelaksanaan implementasi kebijakan merupakan unsur yang tidak dapat dipisahkan. Adapun indikator dari sumber daya manusia dalam penelitian ini adalah kunatitas dan Kualitas SDM, Fasilitas dan dana yang mendukung dalam implementasi kebijakan pos-pos pemadam kebakaran.

\section{- Kuantitas SDM}

Petugas yang terlibat dalam pelaksanaan para petugas yang telah ditetapkan Kepala Badan Penanggulanagan Bencana dan Pemadam Kebakaran. Dalam Tim Penanggulangan bahaya kebakaran dibentuk pos-pos yang bertugas di Kota sampai pos-pos pembantu di Kecamatan.

Di Kota Palembang Tim penanggulangan bahaya kebakaran di bagi 7 (tujuh) pos pembantu yaitu pos merdeka, pos pembantu seberang ulu 2, pos pembantu seberang ulu 1, pos ampera. Pos pembantu sako, pos pembantu alang-alang lebar dan pos pembantu gandus yang masing-masing pos pembantu terdiri dari 10 orang petugas yang masing-masing telah memahami peran dan fungsinya masingmasing sebagaimana diungkapkan oleh Kepala Pos Badan Penanggulangan Bencana dan Pemadam Kebakaran Sebagai Berikut :

"Petugas penanggulangan bencana kebakaaan pada pos pembantu di Kecamatan ini jumlahnya ada sepuluh orang termasuk saya, meskipun hanya sepuluh orang saya berupaya agar yang sedikit ini bisa bekerja dengan efektif, maka saya membagi tugas masingmasing dari mereka dalam wilayah kerja yang telah ditetapkan. Dengan begitu saya harapkan mereka lebih bertanggungjawab dan tahu betul dan fokus terhadap permasalahan yang terjadi masing masing. Tim petugas ini sudah ditentukan dari Kepala Dinas, mungkin ada kaitannya dengan hak honor yang diberikan. Oleh karena itu disini yang ikut saja toh 10 orang kalau bekerja dengan efektif itu sudah cukup".

Pernyataan tersebut menggambarkan bahwa Tim Petugas Tingkat Kecamatan yang berjumlah sepuluh orang telah cukup berfungsi sebagai pengendali penanggulanagan bila terjadi bahaya kebakaran yang berskala kecil di tingkat Kecamatan. Sebagimana dikemukakan petugas/staf yang mengemukakan hal-hal sebagai berikut :

"Selama ini tidak ada masalah mas komunikasi dengan Kecamatan berjalan dengan baik setiap persoalan yang muncul selalu bisa dibantu dengan baik oleh petugas kecamatan".

Berdasarkan pernyataan tersebut terlihat bahwa secara persoalan-persoalan pertolongan penanggulan bila terjadi bahaya kebakaran dapat teratasi, tetapi tetap saja persoalan yang yang terjadi masih ada. Kendala tersebut misalnya apabila terjadi kebakaran yang besar jumlah personil yang hanya 10 orang tadi di rasa masih belum cukup memadai.

\section{- Kualitas SDM}

Secara umum kapasitas petugas Pemadam Kebakaran di Kota Palembang dan Pos-Pos Pembantu di Kecamatan ditinjau dari aspek tingkat Pendidikan cukup baik. Hal ini terlihat pada komposisi tingkat pendidikan pegawai dan petugas pemaam kebakaran pada Badan 
Penanggulangan Bencana dan Pemadam Kebakaran sebagaimana Tabel berikut ini :

\section{Tabel 2}

Tingkat Pendidikan Pegawai dan Petugas Pemadam Kebakaran Kota Palembang

\begin{tabular}{|c|c|c|c|}
\hline No & $\begin{array}{c}\text { Tingkat } \\
\text { Pendidikan }\end{array}$ & $\begin{array}{c}\text { Jumlah } \\
\text { (orang) }\end{array}$ & $\begin{array}{c}\text { Persentase } \\
(\boldsymbol{\%})\end{array}$ \\
\hline 1 & S2 & 9 & 4,35 \\
\hline 2 & S1 & 91 & 23,91 \\
\hline 3 & D3 & 14 & 65,22 \\
\hline 4 & SMA/SMU & 276 & 6,52 \\
\hline & Jumlah & 413 & 100 \\
\hline
\end{tabular}

Sumber: Data Kantor PBPBK 2014

Data tersebut menunjukkan rata-rata petugas pemadam Kebakaran di Badan Penanggulangan Bencana dan Pemadam Kebakaran berpendidikan SLTA. Hal ini menunjukkan kondisi yang cukup baik dan tingkat pendidikan yang baik ini diharapkan juga akan berpengaruh terhadap kinerja implementasi kebijakan petugas pemadam kebakaran. Meskipun tidak ada data yang menunjukkan kaitan langsung antara Tingkat Pendidikan Petugas dengan keberhasilan pemadam kebakran, setidaknya dengan tingkat pendidikan yang cukup maka tingkat pemahaman dan kreatifitas seseorang dalam memahami suatu kebijakan akan lebih baik.

Sumber daya manusia atau pegawai Badan Penanggulangan Bencana dan Pemadam Kebakaran 413 orang yang mayoritas pendidikan rata-rata menengah keatas. Seperti yang diugkapkan oleh Kepala Badan Penanggulangan Bencana dan Pemadam Kebakaran mengatakan:

"Petugas yang ditugaskan sebagai petugas lapangan dalam pelaksanaan pemadam kebakaran di Pos-Pos Pembantu dilihat dari segi kualitas sudah cukup memadai berpendidikan rata-rata menangah keatas dan diploma 3, dan dari segi kuantitas sudah cukup terpenuhi untuk setiap kecamatan".

Berdasarkan penjelasan di atas dapat dilihat bahwa sumber daya manusia yang ada dalam pelaksanaan pertolongan pemadam kebakaran pada Badan Penanggulangan Bencana dan Pemadam Kebakaran untuk kualitas cukup memenuhi kriteria sebagai petugas pelaksanaan Penanggulangan Bencana dan Pemadam Kebakaran.

Sedangkan pendapat salah petugas lapangan mengatakan"

"Sebagai seorang yang diberi kepercayaan melaksanakan tugas dalam menanggulangi bahaya kebakaran, kami selalu berusaha meningkatkan kemampuan yang ada pada diri kami sesuai dengan kebutuhan dan tutuntan yang dibutuhkan, meskipun bidang profesi kami tidak sesuai dengan jenis pekerjaan yang kami lakukan"

Dalam pelaksanaan penanggulangan bahaya kebakaran, dibutuhkan organisasi yang ideal guna menunjang kegiatan pelayanan bantuan bila terjadi kebakaran secara optimal dan memberikan pelayanan yang memuaskan bagi masyarakat.

Dari hasil penelitian di ketahui bahwa sumber daya manusia sebagai pelaksana dalam penanggulangan bahaya kebakaran di Kota Palembang telah melaksanakan tugasnya dan fungsinya dengan baik, hanya saja untuk pelaksanaan di lapangan masih terdapat kendala dimana masih kurangnya kuantitas dari petugas pemadam kebakaran. Dari hasil wawancara tersebut untuk pelaksanaan kerja petugas dilapangan sudah baik. Sejalan dengan hasil wawancara di atas juga diperoleh informasi dari Kepala Badan Penanggulangan Bencana dan Pemadam Kebakaran sebagai berikut:

"Mengenai SDM pelaksanaan penanggulangan bahaya kebakaran, untuk wilayah di Kota Palembang sudah mampu melaksanakan tugasnya dengan baik. Petugas yang ada masih kurang memadai dalam hal jumlah dan tingkat pendidikan."

Berdasarkan penjelasan di atas, diketahui dari segi sumber daya manusia petugas pelaksana penanggulanagan bahaya kebakaran di Kota Palembang dirasakan sudah cukup memadai dalam segi kualitas pendidikan dari petugas lapangan.

- Dana 
Analisa pada indikator ini bertujuan untuk melihat ketersediaan dana anggaran operasional yang digunakan dalam Badan Penanggulangan Bencana dan Pemadam Kebakaran Kota Palembang adalah dari Anggaran Penapatan Belanja Daerah (APBD).

Dana merupakan salah satu sumber daya yang diperlukan dala pelaksanaan suatu kegiatan atau program, begitu juga dalam pelaksanaan Badan Penanggulangan Bencana dan Pemadam Kebakaran Kota Palembang juga memerlukan adanya ketersediaan dana pelaksanaan kegiatannya. Dari hasil penelitian diketahui bahwa, dana yang digunanakan dalam rangka pelaksanaan Badan Penanggulangan Bencana dan Pemadam Kebakaran Kota Palembang berasal dari Anggaran Pendapatan Belanja Daerah.

Dari hasil wawancara penulis kepada Kepala Badan Penanggulangan Bencana dan Pemadam Kebakaran Kota Palembang diperoleh informasi sebagai berikut:

"Seperti program dan kegiatan lainnya, Bantuan Penanggulangan Bencana dan Pemadam Kebakaran Kota Palembang juga memerlukan adanya dana operasional kegiatan, dana yang ada bersumber dari Anggaran Pendapatan Belanja Daerah (APBD). "

Selanjutnya juga diperoleh informasi dari Petugas Badan Penanggulangan Bencana dan Pemadam Kebakaran di Pos-Pos Kecamatan dalam wawancara berikut mengatakan:

"Memang untuk melaksanakan Bantuan

Penanggulangan Bencana dan Pemadam

Kebakaran tentunya memerlukan dana operasional, dana ini kami ajukan pada Kepala Badan BPBPK Kota Palembang, dari dana yang tersedia dirasakan sudah cukup memadai."

Sedangkan menurut kabid sarana dan prasarana yang penulis wawancarai mengatakan:

"Memang benar Badan Penanggulangan

Bencana dan Pemadam Kebakaran Kota Palembang memberikan dana operasional dalam pelaksanaan bantuan Penanggulangan Bencana dan Pemadam Kebakaran apabila terjadi kebakaran”.
Berdasarkan hasil wawancara dan observasi yang penulis lakukan diketahui bahwa sumber dana yang tersedian dirasakan sudah cukup memadai untuk keperluan operasional. Dana tersebut bersumber dari Anggran Pendapatan Belanja Daerah Kota Palembang. Berdasarkan uraian diatas dapat disimpulkan bahwa alokasi dana dalam Badan Penanggulangan Bencana dan Pemadam Kebakaran Kota Palembang sudah cukup memadai.

- Fasilitas Sarana dan prasarana

Sarana adalah segala sesuatu yang dipakai sebagai alat dalam mencapai maksu atau tujuan tertentu. Sedangkan prasarana adalah segala yang merupakan penunjang terselenggaranya suatu proses atau usaha, pembangunan, proyek dan sebagainya.

Dalam melaksanakan bantuan bandan penanggulangan bencana dan pemadam kebakaran Kota Palembang, terdapat sarana operasional yang diperlukan dalam pelaksanaan tersebut. Adapun sarana operasional tersebut, antara lain:

Tabel 3

Sarana dan Prasarana

\begin{tabular}{|l|l|l|l|}
\hline No & Jenis Sarana & $\begin{array}{l}\text { Jumlah } \\
\text { Unit }\end{array}$ & Keterangan \\
\hline 1 & $\begin{array}{l}\text { Mobil } \\
\text { Pemadam } \\
\text { Kebakaran }\end{array}$ & 28 & Unit \\
\hline 2 & $\begin{array}{l}\text { Mobil } \\
\text { Tangki }\end{array}$ & 8 & Unit \\
\hline 3 & $\begin{array}{l}\text { Mesin } \\
\text { Pompa }\end{array}$ & 8 & Unit \\
\hline 4 & $\begin{array}{l}\text { Mesin } \\
\text { Pompa } \\
\text { Apung }\end{array}$ & 6 & Unit \\
\hline 5 & $\begin{array}{l}\text { Baju Tahan } \\
\text { Api }\end{array}$ & 12 & Set \\
\hline 6 & $\begin{array}{l}\text { Baju Tahan } \\
\text { Panas }\end{array}$ & 8 & Set \\
\hline 7 & Fire jacket & 15 & Set \\
\hline 8 & $\begin{array}{l}\text { Breating } \\
\text { Apparatus }\end{array}$ & 8 & Set \\
\hline 9 & $\begin{array}{l}\text { Selang (1,5” } \\
\text { dan 2,5") }\end{array}$ & 200 & Rol \\
\hline 10 & $\begin{array}{l}\text { Breecing } \\
\text { (Cabang } \\
\text { Tiga) }\end{array}$ & 20 & Buah \\
\hline 11 & Nozzle & 60 & Buah \\
\hline 12 & Tandon Air & $128 \mathrm{~m} 2$ & \\
\hline
\end{tabular}

Sumber: Hasil penelitian 2014 
Pada pelaksanaan penanggulangan bencana dan pemadam kebakaran sarana operasional tersebut telah tersedia dan dapat digunakan secara layak, namun dari segi pos pelayanan yang berguna untuk penyampaian informasi atau penyebaran informasi belum dapat berfungsi dengan baik dikarenakan dimana belum adanya tempat pelayanan bantuan penanggulangan padarurat pada setiap kecamatan. Hal ini tentunya masih menjadi kendala dalam pelaksanaan penanggulangan bencana dan pemadam kebakaran di Kota Palembang.

Berikut hasil wawancara yang disampaikan oleh petugas petugas penanggulangan bencana dan pemadam kebakaran tingkat kecamatan mengatakan:

"Mengenai sarana atau alat kelengkapan dalam penanggulangan bencana dan pemadam kebakaran sudah cukup memadai, hanya saja pada pelaksanaan di tingkat kecamatan masih dirasakan terdapat kendala dimana belum adanya tempat pelayananan yang disediakan disetiap kecamatan ". (Wawancara, 5 Jnui 2014)

Infromasi tersebut sejalan dengan hasil wawancara yang dilakukan kepada kabid rehabilitasi dan kontruksi yang masngatakan bahwa:

"Seharusnya memang disediakan tempat pelayanan bagi masyarakat di kecamatan, namun pada kecamatan kami belum ada tempat pelayanan penanggulangan bencana dan pemadam kebakaran sehingga petugas sulit ungantuk memberikan pelayanan apabila terjadi kebakaran yang terjadi pada warga masyarakat". (Wawancara, 5 September 2014)

Dari pernyataan narasumber di atas, diketahui bahwa sarana dan prasarana yang ada dalam penanganan penanggulangan bencana dan pemadam kebakaran di Kota Palembang sudah cukup memadai.

Berdasarkan uraian hasil penelitian dapat disimpulkan bahwa sarana dan prasarana sebagai sumber daya dalam penelitian masih terdapat kekurangan dalam hal tersedianya tempat pelayanan penerima bantuan bencana kebakaran.
Kondisi ketersediaan sarana penunjang dalam penanggulangan bencana dan pemadam kebakaran dipaparkan melalui beberapa wawancara dengan Kabid Sarana dan prasarana Badan Penanggulanagan Bencana dan Pemadam Kebakaran mengatakan bahwa:

"Sarana dan prasarana yang dimiliki oleh

Badan Penanggulangan Bencana dan Pemadam Kebakaran sudah lumayan lengkap, seperti mobil, baju tahan api, baju tahan panas dan lain-lainnya sudah cukup lengkap sehingga dalam melaksanakan bantuan apabila terjadi kebakaran dapat dilakukan dengan cukup baik oleh petugas". (Kabid Sarana dan

Prasarana, 25 September 2014)

Dari beberapa pernyataan narasumber, terlihat sebagian besar narasumber berpendapat bahwa sarana dan prasarana yang ada pada Badan Penanggulangan Bencana dan Pemadam Kebakaran Kota Palembang sudah cukup memadai. Sementara sarana tempat atau peralatan pemadam kebakaran guna melaksnakan bantuan bencana kebakran sudah tersedia sesuai dengan kebutuhan.

3. Disposisi

a. Komitmen petugas

Dari penelitian yang dilakukan penulis, sebagaimana dinyatakan oleh beberapa informan sebagai berikut :

Wawancara kepada kepala dinas beliau mengatakan:

"Sebagai kepala dinas saya berusaha bersikap komitmen dalam mengambil kebijakan terhadap perintah dan pekerjaan yang harus dilakukan".

Hal senada di katakan oleh petugas pemadam kebakaran Riza Surya mengatakan:

"Sebagai petugas yang penting informasi dari atasan saya terima,karena saya juga pelaksana dari kebijakan yang di berikan oleh pimpinan meskipun pekerjaan itu bertentangan dengan hati nurani tapi saya tetap komitmen dalam melaksanakannya".

Pernyataan di atas disampaikan oleh bidang rehabilitasi dan rekontruksi sebagai berikut :

"Itu masalahnya, petugas memang bekerja sesuai dengan prosedur/petunjuk. Petugas pada pos-pos kecamatan menyampaikan informasi dengan cepat 
apabila terjadi kebakaran, sehingga dari petugas pos-pos pembantu yang lain dengan cepat memberikan bantuan apabila dibutuhkan".

Faktor Disposisi/ Watak/ Komitmen Petugas disampaikan oleh Meter dan Horn, Mazmanian dan Sabatier maupun Edwards. Dari pernyataan beberapa informan dapat penulis simpulkan bahwa petugas komitmennya cukup baik, walaupun petugas sebagai seorang pegawai negeri sipil yang bersangkutan harus tetap mempunyai komitmen dalam bekerja harus tetap sesuai sesuai ketentuan.

\section{Struktur Organisasi}

Robbins (2007) mendefinisikan struktur organisasi sebagai penentuan bagaimana pekerjaan dibagi, dibagi, dan dikelompokkan secara formal. Sedangkan organisasi merupakan unit sosial yang dikoordinasikan secara sadar, terdiri dari dua orang atau lebih, dan berfungsi dalam suatu dasar yang relatif terus-menerus guna mencapai serangkaian tujuan bersama.

Dalam konteks desain organisasi, Ivancevich (2008) mendefinisikannya sebagai proses penentuan keputusan untuk memilih alternatif kerangka kerja jabatan, proyek pekerjaan, dan departemen. Dengan demikian, keputusan atau tindakan-tindakan yang dipilih ini akan menghasilkan sebuah struktur organisasi.

\section{- SOP (Standar Operasional Prosedur)}

Menurut Tjipto Atmoko, Standar Operasional Prosedur merupakan suatu pedoman atau acuan untuk melaksanakan tugas pekerjaan sesuai denga fungsi dan alat penilaian kinerja instansi pemerintah berdasarkan indikator-indikator teknis, administratif dan prosedural sesuai tata kerja, prosedur kerja dan sistem kerja pada unit kerja yang bersangkutan.

Banyak orang tidak terlalu mempedulikan proses, namun lebih cenderung kepada hasil semata. Padahal jika kita fahami dengan baik bahwa hasil yang baik tentunya dihasilkan oleh berlangsungnya proses yang baik pula. Kaitannya dengan efektivitas pelaksanaan rehabilitasi, proses merupakan hal utama yang menjadi tujuan, dimana proses yang dilakukan oleh petugas rehabilitasi mulai dari pelayanan, pengobatan sampai dengan penyembuhan harus sesuai dengan aturan-aturan dan ketentuan yang telah ditetapkan.

Adapun SOP dalam penelitian ini adalah tentang Standar Operasional Prosedur dalam implementasi kebijakan penempatan pos-pos pemadam kebakran yang dilaksanakan oleh dinas penanggulangan bencana dan pemadam kebakaran Kota Palembang. Dari analisis yang penulis lakukan berdasarkan waancara dari beberapa informan mengatakan:

"Badan Penanggulanagan Bencana dan Pemadam Kebakaran Kota Palembang dalam melaksanakan kegiatan organisasi selalu berlandaskan kepada standar operasional perosedur yang telah ditetapkan dalam tata kerja organisasi dinas penanggulangan bencana dan pemadam kebakaran" (wawancara kepada kepala dinas BPBPK, 5 September 2014)

Dalam pelaksanaan kebijakan penanggulangan bencana dan pemadam kebakaran khusus nya dalam penempatan pospos pemadam kebakaran kepala dinas selalu berpedoman kepada SOP yang ada.

Seperti halnya yang dikatakan oleh Kepala Bidang sarana dan prasarana mangatakan:

“ Dalam hal pelaksanaan kerja dan kebijakan dalam penempatan pos-pos pemadam kebakaran di dinas penanggulangan bencana dan pemadam kebakran selalu mengacu kepada SOP yang sudah ada". (wawancara kepada kabid sarana dan prasarana, 5 september 2014)

Pernyataan tersebut didukung oleh petugas/staf pemadam kebakaran yang mengatakan bahwa:

" kami dalam melaksanakan tugas dalam memberikan bantuan penanggulangan kebakaran selalu mematuhi struktur organisasi dan standar operasional prosedur yang telah ditetapkan pada dinas penanggulangan bencana dan pemadam kebakaran kota palemabang.". (wawancara kepada Arianando, 5 September 2014). 
Berdasarkan pernyataan tersebut diatas dapat diperoleh jawaban dari indikator struktur organisasi dan sop dalam implementasi kebijakan penenpatan pos-pos pemadam kebakran Kota Palembang sudah baik. Jadi kesimpulan yang penulis ambil bahwa struktur organisasi dalam implementasi kebijakan penempatan pos-pos pemadam kebakaran di kota palembang sudah baik.

\section{Pembahasan Hasil Penelitian}

Hasil analisis dalam penelitian ini dilihat dari ke 4 dimensi sebagai berikut: Dalam kebijakan penempatan pos-pos pemadam kebakaran komunikasi yang dilakukan oleh Badan Penanggulangan Bencana dan Pemadam Kebakaran sudah cukup baik, baik dari tarsmisi, kejelasan dan konistensi. Hal ini terlihat dari hasil wawancara penulis dari ketiga indikator tarnsmisi berdasarkan jawaban informan cukup baik, kejelasan dari hasil wawancara penulis kepada beberapa informan jawaban yang diberikan sudah baik dan konsitensi berdasarkan hasil wawancara juga semua informan mengatakan sudah baik. Artinya dari dimensi komunisasi dengan indikator-indikator yang ada kesimpulannya sudah baik.

Sumber daya manusia teridri dari indikator sumber daya pelaksana, fasilitas dan dana. Berdasarkan hasil penelitian di lapangan dan wawancara untuk indikator kuantitas sumber daya manusia berdasarkan hasil wawancara penulis belum cukup memadai. Hal ini terlihat dari jumlah jumlah personil yang hanya 10 orang apabila terjadi bencana kebakaran yang cukup besar masih belum bisa memberikan bantuan dengan optimal. Dari segi kualitas berdasarkan hasil wawancara yang penulis lakukan sudah cukup memadai.

Berdasarkan hasil wawancara dan observasi yang penulis lakukan diketahui bahwa sumber dana yang ada sudah cukup memadai untuk keperluan operasional. Dana tersebut bersumber dari Anggran Pendapatan Belanja Daerah Kota Palembang.

Sarana dan prasarana yang ada pada Badan Penanggulangan Bencana dan Pemadam Kebakaran Kota Palembang sudah cukup memadai. Sementara sarana tempat atau peralatan pemadam kebakaran guna melaksnakan bantuan bencana kebakran sudah tersedia sesuai dengan kebutuhan.

Disposisi/Watak/Komitmen Petugas disampaikan oleh Meter dan Horn, Mazmanian dan Sabatier maupun Edwards. Berdasarkan hasil wawancara dari beberapa informan bahwa petugas komitmennya cukup baik, walaupun petugas sebagai seorang pegawai negeri sipil yang bersangkutan harus tetap mempunyai komitmen dalam bekerja harus tetap sesuai sesuai ketentuan.

Dimensi struktur organisasi dengan indikator standar operasional prosedur dalam implementasi kebijakan penenpatan pos-pos pemadam kebakran Kota Palembang bahwa struktur organisasi dalam implementasi kebijakan penempatan pos-pos pemadam kebakaran di kota palembang sudah baik.

Tabel 4

Rekapitulasi Hasil Penelitian Implementasi Kebijakan Penempatan Pos-Pos Pemadam Kebakaran Kota Palembang

\begin{tabular}{|c|c|c|}
\hline Dimensi & Indikator & $\begin{array}{l}\text { Hasil } \\
\text { Penelitian }\end{array}$ \\
\hline 1. komunikasi & a. Transmisi & $\begin{array}{l}\text { Cukup } \\
\text { baik, hal } \\
\text { ini } \\
\text { didukun } \\
\text { g dari } \\
\text { hasil } \\
\text { wawanca } \\
\text { ra } \\
\text { kepada } \\
\text { beberapa } \\
\text { informan } \\
\text { bahwa } \\
\text { transmisi } \\
\text { di } \\
\text { BPBPK } \\
\text { Kota } \\
\text { Palemba } \\
\text { ng sudah } \\
\text { cukup } \\
\text { baik.. }\end{array}$ \\
\hline & b. Konsistensi & $\begin{array}{l}\text { Sudah } \\
\text { baik, hal } \\
\text { ini } \\
\text { terlihat } \\
\text { dari } \\
\text { kepatuha } \\
\text { n } \\
\text { petugas } \\
\text { dalam } \\
\text { melaksa } \\
\text { nakan } \\
\text { perintah }\end{array}$ \\
\hline
\end{tabular}




\begin{tabular}{|c|c|c|}
\hline & & atasan. \\
\hline & c.Kejelasan & $\begin{array}{l}\text { Sudah baik, } \\
\text { karena } \\
\text { kejelasan } \\
\text { kebijakan dari } \\
\text { pimpinan dan } \\
\text { perintah yang } \\
\text { diberikan } \\
\text { tidak } \\
\text { membingung } \\
\text { kan. }\end{array}$ \\
\hline \multirow[t]{4}{*}{$\begin{array}{l}\text { 2. sumber daya } \\
\text { manusia }\end{array}$} & a. Kuantitas SD & $\begin{array}{l}\text { Cukup baik, } \\
\text { dari hasil } \\
\text { wawancara } \\
\text { penulis } \\
\text { bahwa dalam } \\
\text { setiap pos } \\
\text { pembantu ada } \\
10 \text { personil } \\
\text { yang } \\
\text { ditugaskan. }\end{array}$ \\
\hline & b. Kualitas SDM & $\begin{array}{l}\text { Cukup dari } \\
\text { segi kualitas } \\
\text { pendidikan }\end{array}$ \\
\hline & c. Dana & $\begin{array}{l}\text { Sudah } \\
\text { memadai, hal } \\
\text { ini didukung } \\
\text { dari hasil } \\
\text { wawancara } \\
\text { bahwa dana } \\
\text { operasional } \\
\text { berasal dari } \\
\text { APBD }\end{array}$ \\
\hline & $\begin{array}{l}\text { d. Fasilitas } \\
\text { Prasarana }\end{array}$ & $\begin{array}{l}\text { Cukup } \\
\text { memadai } \\
\text { hal ini } \\
\text { didukun } \\
\text { g dari } \\
\text { jawaban } \\
\text { informan } \\
\text { prasaran } \\
\text { a yang } \\
\text { ada } \\
\text { sudah } \\
\text { memehu } \\
\text { ni } \\
\text { standar. }\end{array}$ \\
\hline 3. disposisi & $\begin{array}{l}\text { a.Komitmen } \\
\text { petugas }\end{array}$ & $\begin{array}{l}\text { Cukup } \\
\text { komitmen, } \\
\text { hal ini dari } \\
\text { tanggung } \\
\text { jawab petugas } \\
\text { dalam } \\
\text { melaksanakan } \\
\text { pekerjaan } \\
\text { meskipun } \\
\text { mereka } \\
\text { berstatus } \\
\text { PNS. }\end{array}$ \\
\hline
\end{tabular}

\begin{tabular}{|l|l|l|}
\hline 4.Struktur & a. SOP & $\begin{array}{l}\text { Sudah baik, } \\
\text { Birokrasi }\end{array}$ \\
& & petugas bahwa \\
& & dalam \\
& & melaksanakan \\
& & setiap \\
& & pekerjaan \\
& & berasarkan \\
& struktur yang \\
& & ada. \\
\hline
\end{tabular}

Sumber diolah dari hasil penelitian 2014

\section{E. KESIMPULAN}

Berdasarkan hasil penelitian dan pembahasan maka dapat disimpulkan sebagai berikut:

1. Bahwa yang pernah dilakukan oleh Badan Penanggulangan Bencana dan Pemadam Kebakaran Kota Palembang dalam memberikan bantuan bila terjadi kebakaran mengacu pada Standar Operasional Prosedur yang telah ditetapkan oleh Badan Penanggulangan Bencana dan Pemadam Kebakaran.

2. Implementasi kebijakan tentang penemptan pos-pos pemaam kebakaran di Kota Palembang untuk komunikasi sudah berjalan dengan baik, dan juga transmisi, konsistensi dan kejelasan dalam perintah yang diberikan sudah berjalan dengan baik. Hal ini terlihat dari 4 indikator yang dipergunakan yang berjalan dengan baik.

3. Bahwa sumber daya manusia yang ada pada dinsa penanggulangan bencana dan pemadam kebakaran kota palembang dari segi kualitas dan kuantitas juga sudah cukup baik. Fasilitas sarana dan prasarana serta dana operasional dalam pelaksanaan implementasi juga sudah baik.

4. Disposisi komitmen dari petugas dan pegawai dinas penanggulangan bencana dan pemadam kebakaran sudah cukup baik. Hal ini terlihat dari kerja yang dilakukan oleh petugas meskipun mereka berstatus PNS tetapi tetap bekerja sesuai dengan apa yang diperintahkan oleh pimpinan.

5. Bahwa struktur birokrasi pada dinas penanggulangan bencana dan pemadam kebakaran kota palembang juga sudah baik karena mereka bekerja berdasarkan standar operasional prosedur yang berlaku. 


\section{DaftarPustaka}

A.A. Anwar Prabu Mangkunegara. 2001, Manajemen sumber daya manusia perusahaan, Bandung : Remaja Rosdakarya Agustino Leo. 2008. Dasardasar Kebijakan Publik. Bandung:Alfabetha

Badjuri, Abdulkahar dan Yuwono, Teguh, 2002, Kebijakan Publik: Konsep dan Strategi. Semarang: Universitas Diponegoro

Dunn, William N. 2000. Pengantar Analisa Kebijaksanaan Publik. Yogyakarta:PT Prasetia Widia Pratama

Grindle, Merilee S. 1980. Politics and Policy Implementation in The Third World, Princnton University Press, New Jersey

Howlett, Michael, dan M. Ramesh. (1995). Studying Public Policy, Policy Cycles and Policy Subsystem, Oxford, Oxford University Press. Joni, T. Raka .2004. Penelitian dan pengembangan dalam pembaharuan pendidikan. Jakarta. Penerbit: Departemen Pendidikan dan Kebudayaan Proyek Pengembangan

Laswell, Harold, dan Abraham Kaplan. 1970. Power and Society, New Heaven, Yale University Press

Moleong, Lexy. 2006. Metode Penelitian Kualitatif. Bandung: Remaja Rosda Karya

Nawawi Hadari, dan Martini, 1990.Metode Penelitian Bidang Sosial, Gadjah Mada, Yogyakarta. Universitas Press

Singarimbun, Masri, dan Sofian Effendi, 1995, Metode Penelitian Survai, LP3ES, Jakarta

Suwitri, Sri, 2008, Konsep Dasar Kebijakan Publik, Badan Penerbit Universitas Diponegoro, Semarang

Subarsono, AG. 2005,. Analisis Kebijakan Publik: Konsep, Teori dan Aplikasi. Yogyakarta, Pustaka Pelajar, Cetakan Ke-3. Singarimbun, Masri, Sofian Effendi. 2005. Metode Penelitian Survei. PT. Pustaka LP3ES
Sedarmayanti. 2001. Sumber Daya Manusia dan Produktivitas Kerja. Mandar Maju,Bandung.

Sutopo, H.B. Metodologi Penelitian Kualitatif. 2002. Surakarta: Sebelas Maret: University Press

Riant Nugroho D. 2008, Public Policy, Edisi Revisi, Jakarta, Elex Media Komputindo.

Robbins, Stephen, P., and Timothy, A.J. 2008. Perilaku Organisasi (Organizational Behavior, terjemahan Diana Angelica). Buku I dan II. Edisi Keduabelas.Jakarta: Salemba Empat

Ratminto, Atik Septi Winarsih. 2008. Manajemen Pelayanan. Yogyakarta: Pustaka Pelajar

Tilaar, H.A.R. \& Nugroho, Rian. 2008. Kebijakan pendidikan: pengantar untuk memahami kebijakan pendidikan dan kebijakan pendidikan sebagai kebijakan publik. Yogyakarta: P ustaka Pelajar

Tangkilisan, Hessel Nogi S. 2003. Implementasi Kebijakan Publik: Transformasi Pikiran George Edwards. Yogyakarta, YPAPI

Usman, Nurdin. 2008. Konteks Implementasi Berbaisis Kurikulum. Jakarta: Balai Pustaka

Zamzam, F., \& Aravik, H. 2016. Manajemen SDM Berbasis Syariah, Bogor: CV. RWTC Success 